\title{
Effect of Nutrient Addition on an Oil Reservoir Microbial Population: Implications for Enhanced Oil Recovery
}

Xiaoyi Wang' ${ }^{1}$, Dongmei Li ${ }^{2}$, Phil Hendry², Herbert Volk ${ }^{3}$, Abdul Rashid ${ }^{4}, K^{2} y u$ Liu $^{4}$, Manzur Ahmed ${ }^{3}$, Se Gong ${ }^{3}$, Wan Ata B Wan Daud ${ }^{5}$ and Tara D Sutherland ${ }^{1 *}$

${ }^{1}$ CSIRO Ecosystem Sciences, P.O. Box 1700, Acton, ACT 2601, Australia

${ }^{2}$ CSIRO Food and Nutritional Sciences, P.O. Box 52, North Ryde, NSW 1670, Australia

${ }^{3}$ CSIRO Earth Science and Resource Engineering, P.O. Box 132, North Ryde, NSW 1670, Australia

${ }^{4}$ CSIRO Earth Science and Resource Engineering, P.O. Box 1130, Bentley, WA 6112, Australia

${ }^{5}$ PETRONAS Research Sdn Bhd, Kuala Lumpur, Malaysia

\begin{abstract}
The increasing demand for petroleum is driving the development of technologies including MEOR (Microbial enhanced oil recovery) - the use of microbes within a reservoir to enhance oil recovery. In this study we initially determined that availablitty of suitable carbon sources was limiting microbial growth and metabolism of an oil reservoir microbial community. Subsequently we identified metabolic processes that are initiated after addition of nutrients that addressed this limitation. Four distinct metabolic pathways were stimulated: (i) fermentation of the added nutrient; (ii) methanogenises of the metabolites of fermentation; (iii) accumulation and decay of biomass: and (iv) oxidation/co-metabolism of petroleum. Biomass, when introduced as a nutrient, led to similar increases in live cell numbers in oil reservoir microcosms as addition of molasses. In addition to acting as a nutrient, disrupted microbial biomass led to formation of oil-water emulsions and significant lowering of the interfacial tension. These results suggest biomass manipulation can play an important role in MEOR.
\end{abstract}

Keywords: MEOR; Microbial diversity; Microbial growth; 16S rDNA; Microcosm; Biomass

\section{Introduction}

Oil reservoirs are subsurface structures of rock formations where hydrocarbons are trapped in pores. These hydrocarbons have been exploited globally as a major source of energy since the end of the nineteenth century. Despite increasing demand, it is apparent that in many mature oil provinces the peak of oil production has been reached or exceeded. Primary oil recovery methods, which rely on reservoir pressure forcing the oil up the recovery pipelines often only accesses $5-10 \%$ of the oil within a reservoir. Secondary recovery methods such as injection of fluids to augment the natural flow, and tertiary recovery techniques such as the application of heat, solvents, surfactants or gases can be implemented to increase recovery [1]. However, existing technology typically recovers only $40-45 \%$ of the oil in place [2], and economic improvement to recovery rates are highly desirable.

The continuing demand for energy is driving the development of more efficient oil recovery technologies. Eubacteria and archaea are ubiquitous in many oil reservoirs [3-5]. The use of these organisms to enhance oil recovery (known as Microbial Enhanced Oil Recovery: MEOR) was firstly proposed in the 1920's and has been an area of scientific and commercial interest ever since (for review see for example $[6,7])$. Conceptually, MEOR involves enhancing the growth and metabolism of microbes within an oil reservoir in a controlled manner so that the products of enhanced metabolic activity lead to physical alterations in the reservoir and subsequent changes in the oil flow behavior. Traditionally the chemicals considered to be of significance are metabolic by-products such as gases (e.g., $\mathrm{H}_{2}, \mathrm{CH}_{4}, \mathrm{CO}_{2}, \mathrm{~N}_{2}$ ), organic acids (e.g. formate, acetate, lactate, butyrate), solvents (e.g. ethanol and other low molecular weight alcohols, ketones), biosurfactants (e.g. glycolipids, phospholipids, lipopeptides) and microbial polymers such as exopolysaccharides [2,8-13]. MEOR relies on changing the microbial metabolic status quo within the reservoir, to date by the addition of nutrients into the reservoir to enhance microbial metabolism. Exogenous microbes may also be introduced to augment the native reservoir population, although the benefit of such inoculation remains arguable. While most commercial MEOR service providers inject nutrients together with exogenous microbes, the effect of the nutrients alone or nutrients and equivalent amounts of non-viable cell mass are rarely documented, the studies rarely demonstrate that exogenous microbes do become established in the petroleum reservoir, and non have demonstrated benefits that can be solely attributed to exogenous microbes [13]. Nutrient/microbe addition results in an increase in microbial cell number and metabolism and consequently metabolic byproducts, which may lead to physical alterations in the reservoir and enhanced oil recovery. Enhanced microbial growth and metabolism requires energy as well as the components needed for growth, with the exact requirements differing from organism to organism. Energy generation often depends on an external redox partner, which enables the transfer of electrons from reduced donor molecules (organic or inorganic) to acceptor molecules (organic or inorganic). In the reduced reservoir environment it is generally assumed that availability of electron acceptors are more likely to be limiting than electron donors. Growth depends on carbon, oxygen, nitrogen, phosphorus and sulfur nutrients at relatively high concentrations and many other atomic

*Corresponding author: Tara D. Sutherland, CSIRO Ecosystem Sciences, Clunies Ross Street, Acton, ACT 2601, Australia, Tel: +61-2-62464236; Fax: +612-62464000; E-mail: Tara.Sutherland@csiro.au

Received January 20, 2012; Accepted March 05, 2012; Published March 07, 2012

Citation: Wang X, Li D, Hendry P, Volk H, Rashid A, et al. (2012) Effect of Nutrient Addition on an Oil Reservoir Microbial Population: Implications for Enhanced Oil Recovery. J Pet Environ Biotechnol 3:118. doi:10.4172/2157-7463.1000118

Copyright: () 2012 Wang X, et al. This is an open-access article distributed under the terms of the Creative Commons Attribution License, which permits unrestricted use, distribution, and reproduction in any medium, provided the original author and source are credited. 
species at low, or trace, levels in a form that the microbes can utilize. Many laboratory studies have demonstrated that microbial activity can lead to sufficient physical changes in reservoir fluids to enhance oil recovery in core flooding model systems, and numerous field trials have shown enhanced oil recovery after addition of nutrients (or nutrient/ microbe combinations) into reservoirs, whilst other field trials have not shown the same effects (for review see $[2,11,14,15]$ ).

Despite decades of research and field trials MEOR is not widely used in the petroleum industry. Uptake of the technology has been limited due to engineering issues associated with delivery of material into the reservoir coupled with the lack of predictability of the effect of adding material into the reservoir. The unpredictability of the technology stems in a large part from a lack of fundamental understanding of the metabolic processes that occur in response to MEOR in reservoir microbial communities and the effects that these responses have on the physical properties of the reservoir. For example, despite the apparent efficiencies of many experimental trials, when the microbial pathways believed to be involved in MEOR are used in predictive models, the effects on recovery are predicted to be too small to be economically viable [15]. The discrepancy between experimental and predictive results can only be resolved through a greater understanding of the metabolic processes involved in MEOR.

Frequently, the microbe cell numbers are increased thousand-fold in successful MEOR field trials [16-18]. Previous studies investigating the effect of biomass have investigated three physical effects induced by whole cells: plugging of rock pores; oil-water emulsification; and, effects of cells on wettability of rock surfaces [8,15,19-25]. Plugging studies have been conducted from a practical point of view and have involved establishing microbes at high permeability zones of the reservoirs to block the rock pores and to channel flow towards lower permeability zones which have retained higher oil saturation $[8,20,24,26]$. Other laboratory studies have found that intact bacterial cells behave like colloidal solids absorbing onto fluid-fluid interfaces leading to oil-water emulsions [21-23] or adsorbing on the rock surface to alter wettability $[19,25]$.

In this study we assume that MEOR requires an increase in either the rate or the nature of microbial metabolism in the reservoir. We initially investigate the composition of the oil fraction in the reservoir and use this information to tailor nutrient mixtures to stimulate metabolism in the extant microbial community in samples from the same reservior. We then address the question of what metabolic pathways are stimulated as a result of nutrient addition by measuring population and metabolite changes that occur in response to nutrient addition. Finally, we investigate in more detail one of the effects of nutrient addition: biomass accumulation and decay.

\section{Materials and Methods}

\section{Collection and analysis of reservoir samples}

Reservoir samples were obtained from an offshore gas-lifting oil field (approximately $800 \mathrm{~m}$ deep and at $50^{\circ} \mathrm{C}$ ) in Malaysia [27]. The tested reservoir compartment had not been subject to any water flooding or MEOR application. Oil field fluids (20\% oil, $80 \%$ formation water) that were highly gasified with $\mathrm{CO}_{2}$ and $\mathrm{CH}_{4}$ were collected directly from the well-head into sterile $500 \mathrm{~mL}$ bottles. The bottles were completely filled and then immediately stoppered with rubber stoppers that would prevent gas exchange (Schott, Australia) then transported at ambient temperature to an anaerobic hood in the laboratory. The transient time from collection to the anaerobic hood was 4 months during which time the bottles were not opened. Microcosms were set up from stored samples over a six month period. Storage did not have any noticeable effect on the microbial population that responded to molasses addition with similar populations growing in after prolonged storage (see population observed in samples grown in the presence of molasses below).

Asphaltenes were precipitated from ca. $150 \mathrm{mg}$ of oil by dissolving in an excess of $n$-pentane after the oil had been separated from the formation water by passing settled oil-water mixtures through a separatory funnel. The isolated maltene fraction was passed through a silica-alumina column (Merck, Australia) and the aliphatic hydrocarbon fraction was eluted using $\sim 100 \mathrm{~mL}$ petroleum ether. The aromatic hydrocarbon fraction was then eluted using $\sim 100 \mathrm{~mL} \mathrm{4:1} \mathrm{mixture} \mathrm{of}$ dichloromethane and petroleum ether. GC-MS of the aliphatic and aromatic hydrocarbon fractions was performed on a Hewlett Packard 5890 GC interfaced to a VG AutoSpecQ Ultima MS (electron energy 70 $\mathrm{eV}$; electron multiplier $250 \mathrm{~V}$; trap current $200 \mu \mathrm{A}$; source temperature $250^{\circ} \mathrm{C}$ ) tuned to 1000 resolution. Chromatography was carried out on a DB5MS fused silica column $(60 \mathrm{~m} \times 0.25 \mathrm{~mm}$ i.d.) coated with (5\%-Phenyl)-methylpolysiloxane, using a splitless injection technique. Further details on isolation, fractionation and GC-MS analyses can be found in George et al. [28]. The chemical composition of the formation water was measured by the National Measurement Institute (Perth, Australia).

\section{Microorganisms}

Reservoir microcosms contained untreated formation water and reservoir oil, reducing agents $\left(12.5 \mathrm{gL}^{-1} \mathrm{Na}_{2} \mathrm{~S} ; 12.5 \mathrm{~g} \cdot \mathrm{L}^{-1} \mathrm{~L}\right.$-cysteine; 3 $\mathrm{g} \cdot \mathrm{L}^{-1} \mathrm{NaOH}$ ) to establish a redox potential of around $\mathrm{E}^{\prime}=-243 \mathrm{mV}$ [29], and an anaerobic indicator $\left(0.001 \mathrm{~g} \cdot \mathrm{L}^{-1}\right.$ resazurin) in bottles anaerobically sealed with butyl rubber stoppers. In this system the relative biodiversity and abundance of the native community and the general biochemistry (assuming similar redox levels) and nutrient load found in the reservoir were retained. The microcosms were prepared in an anaerobic chamber (Coy Laboratory Products, MI, USA) supplied with a gas atmosphere of $90 \%$ nitrogen, 5\% carbon dioxide and 5\% hydrogen and kept oxygen-free by the palladium catalysed reaction of hydrogen with any contaminating free oxygen. The chamber was equipped with oxygen and hydrogen sensors (Coy Laboratory Products, MI, USA) which showed that the actual hydrogen concentration, when the chamber was in use, was less than $1 \%$. Microcosms surveying the effect of nutrient augmentation on microbial growth also contained the following nutrients in isolation or combination: molasses, maltose, peptone, starch, yeast extract, glucose, 12-alkane, sucrose, cellulose (soluble and insoluble), vegetable oil, whey, glycerol, $\mathrm{NaNO}_{3},\left(\mathrm{NH}_{4}\right)_{2} \mathrm{SO}_{4}$ and/or $\mathrm{K}_{2} \mathrm{HPO}_{4} / \mathrm{KH}_{2} \mathrm{PO}_{4}$. The nutrients were added to a C:N:P ratio of 32:6.4:1 to approximate levels generally required by microbes [30], equivalent to $0.5 \%$ glucose $\left(2 \mathrm{~g}\right.$ carbon $\left.\cdot \mathrm{L}^{-1}\right), 0.38 \%$ yeast extract $(0.4 \mathrm{~g}$ nitrogen $\left.\cdot \mathrm{L}^{-1}\right)$ and $0.031 \mathrm{~g} \cdot \mathrm{L}^{-1}$ each $\mathrm{K}_{2} \mathrm{HPO}_{4}$ and $\mathrm{KH}_{2} \mathrm{PO}_{4}$. Sulphur (1.89 $\mathrm{g} \cdot \mathrm{L}^{-1}$ ) was added as $\left(\mathrm{NH}_{4}\right)_{2} \mathrm{SO}_{4}$. Molasses (Organic Road brand, Black Strap Organic Molasses) was obtained from Santos Trading (Byron Bay, Australia) and contained 68\% carbohydrates. All other nutrients were obtained from Sigma-Aldrich (Australia). Triplicate microcosms were set up for each nutrient combination. After incubation in the dark at $50^{\circ} \mathrm{C}$ for 14 days, the optical density, cell count and $\mathrm{pH}$ were measured and then the cells collected by centrifugation at $1800 \mathrm{~g}$ for 10 
min. The cell pellets were stored at $-80^{\circ} \mathrm{C}$ until required for community analysis.

Total cell and fluorescent cell numbers were counted using a fluorescent microscope (Leica DMR, Australia) equipped with a FITC filter and a haemocytometer (Hausser Scientific, USA) irradiated with UV light using a FITC emission filter (bandpass 450-490 nm). The total cell number was measured after adding $0.01 \%\left(\mathrm{v} \cdot \mathrm{v}^{-1}\right)$ SYBR green I fluorescent dye (Invitrogen, Australia) followed by $1 \mathrm{~h}$ incubation at $4^{\circ} \mathrm{C}$. Methanogenic microorganisms in the samples were enumerated by their autofluorescence [31]

\section{Molecular methods to characterise microbial diversity}

The microbial diversity in the microcosms was analyzed by generating $16 \mathrm{~S}$ rDNA clone libraries and characterizing ARDRA (Amplified Ribosomal DNA Restriction fragment length Analysis) patterns and $16 \mathrm{~S}$ rDNA clone sequences. Total DNA from aqueous fraction of microcosms was extracted using the FastDNA ${ }^{\circledR}$ SPIN for Soil Kit (MP Biomedicals, Australia) according to the manufacturers' directions. Clone libraries were constructed from 16S rDNA amplicons generated from polymerase chain reactions (PCR) containing 10-40 ng of total DNA, $200 \mu \mathrm{M}$ of the bacteria specific oligonucleotide primers 5'-AGAGTTTGATYMTGGCTC-3' and 5'-GGTTACCTTGTTACGACTT-3' [32] or the archaeal specific primers 5'-TTCCGGTTGATCCYGCCGGA-3' and 5'-YCCGGCGTTGAMTCCAATT-3' [33] with Platinum ${ }^{\circledR}$ Taq DNA polymerase High Fidelity (Invitrogen, Australia). The PCR amplification program consisted of one cycle of $95^{\circ} \mathrm{C}$ for 2 min and then 30 cycles of $95^{\circ} \mathrm{C}$ for $30 \mathrm{~s}, 55^{\circ} \mathrm{C}$ for $30 \mathrm{~s}, 72^{\circ} \mathrm{C}$ for $90 \mathrm{~s}$ and a final $7 \mathrm{~min}$ extension at $72^{\circ} \mathrm{C}$ (eubacterial library). Reaction cycles for the archaeal libraries were the same except that the extension time was $60 \mathrm{~s}$ rather than $30 \mathrm{~s}$. Amplicons were cloned into pSC-B-amp/kan (Stratagene, CA, USA) and transformed into E. coli (DH5a; Promega, Australia). The $16 \mathrm{~S}$ rDNA fragment of 96 clones for microcosms with molasses added and 24 clones for each microcosms where other nutrients had been added were initially re-amplified using the primers described above and the amplicons were digestion with HaeIII restriction endonuclease (New England Biolabs, MA, USA) and separation by electrophoresis on a $6 \%$ polyacrylamide gel (Bio-rad, Australia) or a MultiNA instrument (MCE-202, Shimadzu Biotech, USA). The full length of at least five clones from each ARDRA pattern were sequenced by commercial sequencing facilities (Micromon, Monash University) and the sequences compared by BLAST analysis to sequences available on GenBank.

\section{Microbial metabolite analysis in microcosms}

Changes in the gas composition of the head space of microbial microcosms were analyzed using a CP-3800 gas chromatograph (GC)

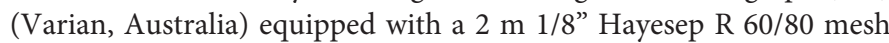
packed column for the separation of hydrocarbon gases and a $2 \mathrm{~m}$ $1 / 8$ ” Molsieve $5 \AA 60 / 80$ mesh packed column for the separation of permanent gases. The gases were detected using a two channel detector system combining a thermal conductivity detector (TCD) and a flame ionisation detector (FID). Carbon dioxide was detected on the FID channel after passing through a methanizer (Varian, Australia). The temperature program had an initial temperature of $80^{\circ} \mathrm{C}$ for $10 \mathrm{~min}$ followed by heating at $15^{\circ} \mathrm{C} \mathrm{min}^{-1}$ to $200^{\circ} \mathrm{C}$ then a $5 \mathrm{~min}$ hold.

Low molecular weight (LMW) and medium molecular weight (MMW) metabolite measurements were conducted after the water phase was separated from the oil using a separatory funnel and then filtered through a $0.22 \mu \mathrm{m}$ hydrophilic membrane filter (Millipore, Australia). Filtered water $(5 \mathrm{~mL})$ was transferred into a $20 \mathrm{~mL}$ screw capped head space vial and 4-methyl-1-pentanol $(5 \mu \mathrm{g})$ was added as an internal standard. The syringe injector of a solid phase microextraction (SPME) unit (Supelco, USA) equipped with a 23-Gauge, $85 \mu \mathrm{m}$, Carboxen/polydimethylsiloxane fibre was inserted through the septum of the vial cap and the fibre was exposed to the headspace for $30 \mathrm{~min}$ at $40^{\circ} \mathrm{C}$. The volatiles were thermally desorbed into a 30 m Solgel-Wax ${ }^{\mathrm{TM}}$ (0.25 mm i.d., $0.25 \mu \mathrm{m}$ film thickness) GC column by placing the SPME injection unit in the injector of an Agilent 6890 series GC interfaced to an Agilent 5972 Mass Spectrometer (MS) using a Shimadzu AOC-5000 auto-injector. Compound separation on the GC column was achieved by heating to $50^{\circ} \mathrm{C}$ for $5 \mathrm{~min}$ and then the temperature was increased by $6^{\circ} \mathrm{C} \mathrm{min}^{-1}$ to $245^{\circ} \mathrm{C}$ with a final hold of $5 \mathrm{~min}$. The MS detector was used in the electron impact (EI) mode with an ionization voltage of $70 \mathrm{eV}$. The data were acquired in full scan mode $(m / z 40-250)$. Compounds were identified by comparison of known mass spectra in the NIST98 Library.

\section{Generation of biomass}

Biomass was derived from two sources: reservoir microbes and E. coli. E. coli was not present in the reservoir samples and therefore E. coli cells were used as a control to ensure that added cells did not directly contribute to increases in cell number. The reservoir microbial biomass was derived from microbes in oil reservoir microcosms after two weeks incubation subsequent to molasses addition. E. coli biomass was derived from DH5a cells (Promega, Australia) cultured in Luria broth at $37^{\circ} \mathrm{C}$ for $16 \mathrm{~h}$. The cell pellets from both sources were collected by centrifugation at $5000 \mathrm{~g}, 4^{\circ} \mathrm{C}$ for $30 \mathrm{~min}$. The cell pellets were washed three times by resuspending in saline $\left(0.91 \% \mathrm{~W} \cdot \mathrm{v}^{-1} \mathrm{NaCl}\right)$ then collecting by centrifugation at $5000 \mathrm{~g}, 4^{\circ} \mathrm{C}$ for $30 \mathrm{~min}$.

For nutrient experiments, the biomass pellets was autoclaved at $121^{\circ} \mathrm{C}, 15 \mathrm{psi}$ for $30 \mathrm{~min}$, and dried overnight at $60^{\circ} \mathrm{C}$. The dried pellets were sealed into purpose-built aluminium foil capsules (SerCon Ltd, UK), for the determination of carbon content using a Europa 20-20 isotope ratio mass spectrometer with an Automated Nitrogen Carbon Analyzer preparation system (SerCon Ltd, UK).

For physical experiments, the biomass was resuspended in distilled water at $10^{10}$ cells $\cdot \mathrm{mL}^{-1}$ (assuming an $\mathrm{OD}_{600}$ reading of 1.0 corresponds to $8 \times 10^{8}$ E. coli cells $\cdot \mathrm{mL}^{-1}$ ), separated into two samples, and then one sample immediately autoclaved at $121^{\circ} \mathrm{C}, 15 \mathrm{psi}$ for $30 \mathrm{~min}$ to generate samples of whole cells and samples of cell components (autoclaved whole cells). Autoclaved solutions were diluted 10, 100, 1000 and 10000 times with synthetic formation water to generate solutions containing the equivalent of $10^{9}, 10^{8}, 10^{7}$ and $10^{6}$ cells. $\mathrm{mL}^{-1}$ for emulsification activity, density, viscosity and interfacial tension (IFT) measurements. The synthetic formation water contained $\left(\mathrm{L}^{-1}\right): 21.60 \mathrm{~g}$ of $\mathrm{NaCl}, 1.42$ $\mathrm{g} \mathrm{MgCl}_{2} \cdot 6 \mathrm{H}_{2} \mathrm{O}, 0.44 \mathrm{~g} \mathrm{CaCl}_{2} .2 \mathrm{H}_{2} \mathrm{O}, 0.36 \mathrm{~g} \mathrm{NaHCO}_{3}, 0.19 \mathrm{~g} \mathrm{KCl}, 83.99$ $\mathrm{mg} \mathrm{NH}_{4} \mathrm{Cl}, 57.75 \mathrm{mg} \mathrm{Na}_{2} \mathrm{Si}_{3} \mathrm{O}_{7}, 46.92 \mathrm{mg} \mathrm{H}_{3} \mathrm{BO}_{3}, 36.50 \mathrm{mg} \mathrm{SrCl} .6 \mathrm{H}_{2} \mathrm{O}$, $20.24 \mathrm{mg} \mathrm{NiCl} .6 \mathrm{H}_{2} \mathrm{O}, 9.87 \mathrm{mg} \mathrm{Na} \mathrm{WO}_{4} .2 \mathrm{H}_{2} \mathrm{O}, 3.20 \mathrm{mg} \mathrm{BaCl} .2 \mathrm{H}_{2} \mathrm{O}$, $1.10 \mathrm{mg} \mathrm{Na} \mathrm{SeO}_{3} 0.65 \mathrm{mg} \mathrm{NaH} \mathrm{PO}_{4} \cdot 2 \mathrm{H}_{2} \mathrm{O}, 0.40 \mathrm{mg} \mathrm{FeSO}_{4} .7 \mathrm{H}_{2} \mathrm{O}, 0.13$ $\mathrm{mg} \mathrm{CoCl} 2.6 \mathrm{H} 2 \mathrm{O}, 0.08 \mathrm{mg} \mathrm{Na} \mathrm{MoO}_{4} .2 \mathrm{H}_{2} 0,0.02 \mathrm{mg} \mathrm{MnSO}_{4} .2 \mathrm{H}_{2} \mathrm{O}, 0.01$ $\mathrm{mg} \mathrm{CuCl}_{2}$ and $0.01 \mathrm{mg} \mathrm{ZnCl}_{2}$.

\section{Assessment of the nutritional effects of biomass}

The ability of reservoir microbes to utilize biomass as a nutrient source was compared to their ability to utilize equivalent amounts of carbohydrate. The equivalent to $2 \mathrm{~g} \cdot \mathrm{L}^{-1}$ carbon of autoclaved biomass or 
molasses was added as a nutrient to microcosms. The microcosms were then incubated for 2 weeks at $50^{\circ} \mathrm{C}$ and then the total and fluorescent cell numbers and microbial diversity were quantified (as described in section 2.5).

\section{Assessment of the physical effects of biomass}

The ability of E. coli whole cell and cell component solutions to emulsify hydrocarbons at different concentrations was determined by the method described by Cooper and Goldenberg [34]. Solutions (4 $\mathrm{mL}$ ) were added to $6 \mathrm{~mL}$ of kerosene (Sigma Aldrich, Australia) and mixed by vortexing at high speed for $2 \mathrm{~min}$. The proportional height of the emulsion layer after $24 \mathrm{~h}$ at room temperature was recorded as the emulsion index $\left(\mathrm{E}_{24}\right)$. Light microscope (Leica M205C, Australia) images of the emulsion droplets were taken using a Leica DFC425 digital camera (Leica, Australia).

The density and viscosity of autoclaved biomass solutions were measured using a DE-40 Density meter (Mettler Toledo, Australia) and a Visco Lab 4000 viscometer (Cambridge Viscosity, MA, USA) respectively at $25^{\circ} \mathrm{C}$ and $50^{\circ} \mathrm{C}$ under ambient pressure. The IFT between the autoclaved biomass solutions and dodecane were measured using an Inverted Pendant Drop Interfacial Tension system IFT-10 (Temco, USA). The inverted pendant drop was viewed through a camera attached to a computer and analysed by DROPimage Advanced software (RaméHart, NJ, USA). Dodecane was used as the droplet (pendant) phase with the autoclaved biomass solution as the external phase. The IFT values were measured between the interface of dodecane and synthetic formation water, at $25^{\circ} \mathrm{C}$ and $50^{\circ} \mathrm{C}$ at ambient pressure, and $50^{\circ} \mathrm{C}$ at $1000 \mathrm{psi}$. The minimum retention time for the pendant drop to reach equilibrium was about $30 \mathrm{~min}$. The IFT measurements were carried out every $5 \mathrm{~s}$ for $500 \mathrm{~s}$ after reaching equilibrium with the reported IFT value calculated from the mean of 100 measurements.

\section{Results}

\section{Analysis of reservoir samples}

The samples used in this study were collected from the wellhead of an off-shore oil reservoir and therefore the ion content of the formation water was compared to that found in sea water to ensure that the samples had not become contaminated by sea water. The sulphate concentration in the formation water was less than 5 ppm, i.e. at levels less than $2 \%$ of those found in sea water (ca. 2798 ppm; [35]) indicating low or no sea water contamination. Other ions were found at 58 (calcium), 32 (chloride), 86 (magnesium), 79 (potassium) and 18 (sodium) \% less concentrated than those reported in sea water.

Analysis of the molecular composition of the reservoir oil by GCMS found predominantly a hump of Unresolved Complex Mixture (UCM, Figure 1), with the resolved compounds on above of this hump being diamondoids, bicyclic sesquiterpanes, steranes and pentacyclic terpanes and low levels of mono-, di-, tri- and tetracyclic aromatic hydrocarbons. Straight-chained paraffins or simple branched chain alkanes were not detected. The molecular composition of the oil was typical for heavily biodegraded oil, where biodegradation of the petroleum on the geological time-scale had removed readily bioavailable compounds, leaving behind compounds resistant to microbial metabolism $[36,37]$.

The total microbial cell number in the formation water was estimated at $2.3 \times 10^{6}$ cells $\cdot \mathrm{mL}^{-1}$. Methanogens, which use the fluorescent cofactor F420 as their primary electron carrier and can be recognized in whole cell counts by their fluorescence, comprised around $4 \%$ of the cells.

\section{Assessment of nutrients limiting microbial growth in reservoir samples}

An experimental microcosm system was developed to identify nutrient combinations that stimulated growth of microbes in reservoir fluids. Generally the nutrients added into the system were variants of nutrients used for MEOR, with additional nutrients added primarily to assess factors limiting growth in the samples. Addition of inorganic nutrients ( $\mathrm{N}, \mathrm{S}$ or $\mathrm{P}$ sources) into the microcosms did not stimulate microbial growth after 2 weeks. Growth was observed only after the addition of organic nutrients (protein, lipid or carbohydrate; data not shown).

\section{Identification of the microbial species that responding to nutrient addition}

A comparative assessment of the microbial diversity in the microcosms after addition of different nutrients found similar ARDRA patterns in all microcosms that responded to nutrients (data not shown). Archaeal and eubacterial $16 \mathrm{~S}$ rDNA clone libraries were

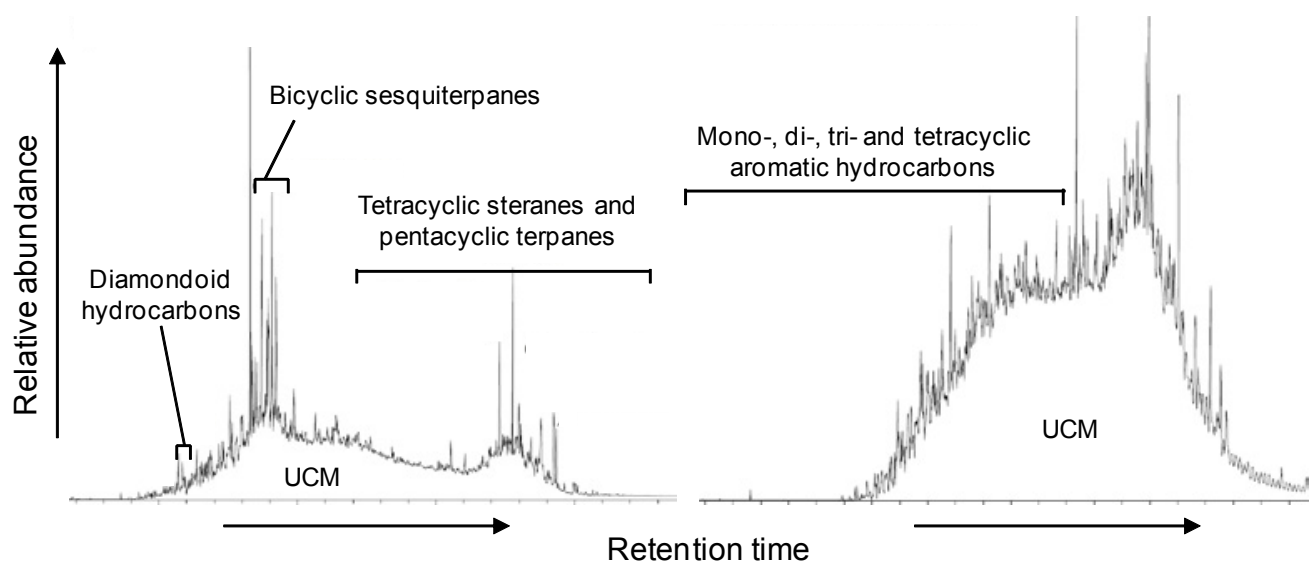

Figure 1: Total ion chromatograms (TIC) for the reservoir oil showing the distribution of aliphatic hydrocarbons (left) and aromatic hydrocarbons (right). UCM = Unresolved Complex Mixture. 
Citation: Wang X, Li D, Hendry P, Volk H, Rashid A, et al. (2012) Effect of Nutrient Addition on an Oil Reservoir Microbial Population: Implications for Enhanced Oil Recovery. J Pet Environ Biotechnol 3:118. doi:10.4172/2157-7463.1000118

Page 5 of 10

constructed using DNA isolated from microcosms after the addition of: glucose plus yeast extract; maltose plus yeast extract; starch plus yeast extract; or molasses with similar sequences identified from each library. Analysis of the sequence of 50 clones revealed 5 eubacterial and 3 archaeal sequence groups. The sequence groups from three of the eubacterial ARDRA groups had greatest (more than 97\%) identity to 16S rDNA genes from fast-growing, fermentative, anaerobic, thermophilic species within the genera Petrotoga Mahella and Anaerobaculum. The remaining groups had $97 \%$ or greater sequence identity to Flexistipes sp. vp180 (Genbank accession number AF220344) and a single sequence was identified with $90 \%$ sequence identity to Chlorobi species. The archaeal sequence groups were most related (over 97\% similarity) to hydrogenotrophic, thermophilic methanogenic species within Methanoculleus, Methanothermobacter and Methanocalculus genera.

\section{Assessment of growth and metabolism in response to molasses addition}

As addition of different carbon-based nutrients stimulated growth of similar communities, measurement of the biochemical changes induced by nutrient addition was conducted on microcosms after addition of molasses. Molasses addition led to increases in total cell number (from $2.3 \times 10^{6}$ up to $4.6 \times 10^{9}$ cells $\mathrm{mL}^{-1}$ ) and fluorescent (methanogenic) cell numbers $\left(8.0 \times 10^{4}\right.$ up to $2.1 \times 10^{9}$ cells $\mathrm{mL}^{-1}$; Figure 2). Microbial growth after molasses addition led to significant

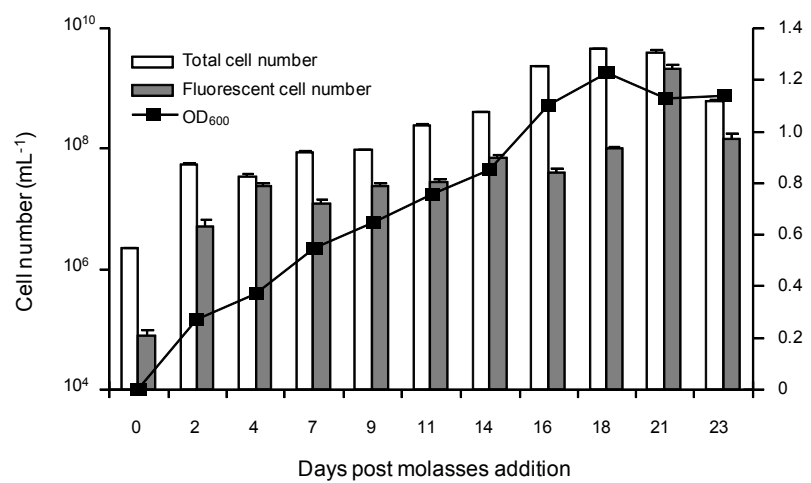

Figure 2: Log scale increases in total and fluorescent cell numbers and linear increases in optical density at $595 \mathrm{~nm}$ (corrected for background) in microcosms after addition of molasses. Error bars are standard errors of the mean.

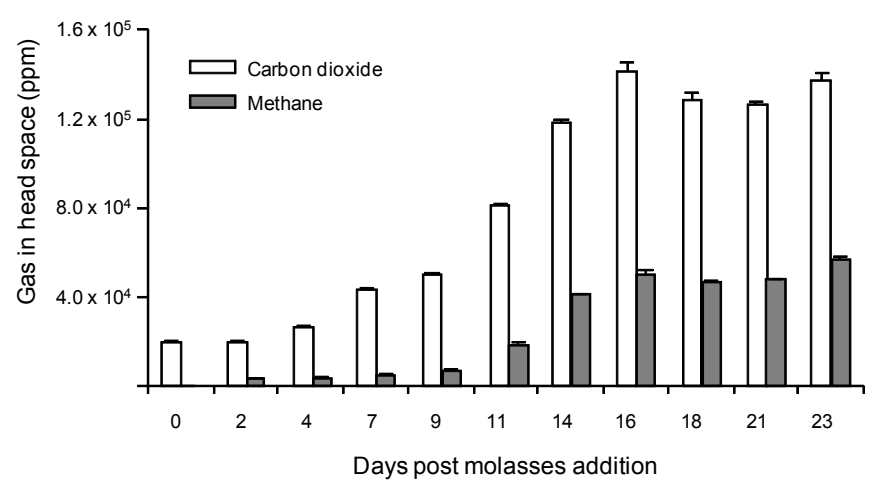

Figure 3: Methane and carbon dioxide concentration in the headspace of microcosms after addition of molasses. Error bars are standard errors of the mean.

\begin{tabular}{|l|c|c|c|}
\hline & \multicolumn{1}{|c|}{ Treatment } & \multicolumn{2}{|c|}{ Controls } \\
\hline Compounds & Molasses addition & No molasses & $\begin{array}{c}\text { Sterilised } \\
\text { microcosm with } \\
\text { molasses addition }\end{array}$ \\
\hline $\begin{array}{l}\text { Alcohols } \\
\text { 1-Propanol }\end{array}$ & + & - & - \\
\hline 1-Butanol & + & - & - \\
\hline 1-Butanol, 2,3-methyl & + & - & - \\
\hline 1-Pentanol & + & - & - \\
\hline 1-Adamantanol & + & - & - \\
\hline Phenol & + & - & - \\
\hline 3-Vanilpropanol & + & - & - \\
\hline Acids & + & - & - \\
\hline Acetic acid & + & - & - \\
\hline Propionic acid & + & - & - \\
\hline Propionic acid, 2-methyl & + & - & - \\
\hline Butanoic acid & + & - & - \\
\hline Butanoic acid, 2-methyl & + & - & - \\
\hline Benzene acetic acid & + & - & \\
\hline
\end{tabular}

+ : compounds detected in the microcosm fluids. - :compounds either not present or present at significantly reduced concentrations.

Table 1: Comparative levels of compounds identified in petroleum reservoir microcosms after addition of molasses and anaerobic culture for 2 weeks at $50^{\circ} \mathrm{C}$ compared to controls.

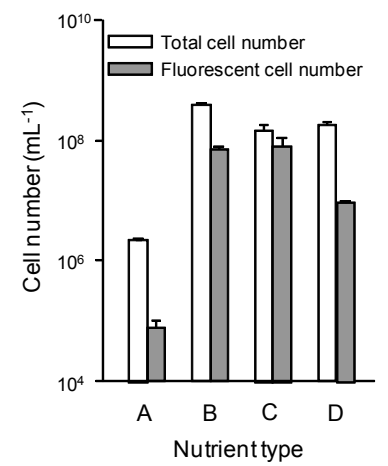

Figure 4: Cell numbers in oil reservoir microcosms after 2 weeks incubation with addition of different nutrient types. A: no nutrient added; B: molasses; C: E. coli biomass; and D: reservoir microbe biomass.

accumulation of carbon dioxide and methane (Figure 3), and accumulation of a number of low and medium molecular weight acids and alcohols not detected in controls (Table 1). No changes in the composition of the oil were observed after incubation with various nutrients. However, the majority of minor changes would be expected to be masked by the complexity of the oil composition. Small variations in timing of growth and the accumulation of metabolites were observed between microcosms.

\section{Microbial biomass as a nutrient for oil reservoir microbial communities}

To compare the extent to which microcosm communites were capable of utilising microbial biomass as a nutrient source, increase in cell numbers after addition of biomass in the form of autoclaved E. coli or reservoir microbe cells were compared to increase in cell numbers observed after equivalent amounts of carbon in the form of molasses. Microscopy analysis confirmed that autoclaving lead to complete lysis of cells (data not shown). Cells were lysed by autoclaving rather than other methods to ensure that the added biomass was sterile. Substantial cell number increases were observed in microcosms 2 weeks after the 
Citation: Wang X, Li D, Hendry P, Volk H, Rashid A, et al. (2012) Effect of Nutrient Addition on an Oil Reservoir Microbial Population: Implications for Enhanced Oil Recovery. J Pet Environ Biotechnol 3:118. doi:10.4172/2157-7463.1000118

Page 6 of 10

\begin{tabular}{|c|c|c|c|c|c|c|c|c|}
\hline \multirow{3}{*}{$\begin{array}{l}\text { Cell concentration } \\
\quad\left(\text { cells } \cdot \mathrm{mL}^{-1}\right)\end{array}$} & \multicolumn{4}{|c|}{ E.coli biomass } & \multicolumn{4}{|c|}{ Reservoir microbe biomass } \\
\hline & \multicolumn{2}{|c|}{ Density $\left(\mathrm{gm} \cdot \mathrm{cc}^{-1}\right)$} & \multicolumn{2}{|c|}{ Viscosity (cP) } & \multicolumn{2}{|c|}{ Density $\left(\mathrm{gm} \cdot \mathrm{cc}^{-1}\right)$} & \multicolumn{2}{|c|}{ Viscosity (cP) } \\
\hline & $25^{\circ} \mathrm{C}$ & $50^{\circ} \mathrm{C}$ & $25^{\circ} \mathrm{C}$ & $50^{\circ} \mathrm{C}$ & $25^{\circ} \mathrm{C}$ & $50^{\circ} \mathrm{C}$ & $25^{\circ} \mathrm{C}$ & $50^{\circ} \mathrm{C}$ \\
\hline 0 & 1.02 & 1.01 & 1.00 & 0.63 & 1.02 & 1.01 & 1.00 & 0.63 \\
\hline $10^{6}$ & 1.02 & 1.01 & 0.96 & 0.61 & 1.02 & 1.01 & 1.08 & 0.67 \\
\hline $10^{7}$ & 1.02 & 1.01 & 1.07 & 0.66 & 1.02 & 1.01 & 0.98 & 0.62 \\
\hline $10^{8}$ & 1.02 & 1.01 & 1.03 & 0.61 & 1.02 & 1.01 & 0.96 & 0.60 \\
\hline
\end{tabular}

Table 2: Effects of varying amounts of biomass on synthetic formation water density and viscosity at different temperatures.

addition of reservoir microbe $\left(1.8 \times 10^{8}\right.$ cells $\left.\cdot \mathrm{mL}^{-1}\right)$ and E. coli $\left(1.5 \times 10^{8}\right.$ cells $\left.\cdot \mathrm{mL}^{-1}\right)$ biomass, approximately equivalent to the response observed with molasses $\left(4.0 \times 10^{8}\right.$ cells $\left.\cdot \mathrm{mL}^{-1}\right)$ (Figure 4$)$. Greatest increases in methanogen number were observed in microcosms fed with $E$. coli biomass $\left(7.8 \times 10^{7}\right.$ cells $\left.\cdot \mathrm{mL}^{-1}\right)$. Substantial increases in fluorescent cells were also observed in those fed molasses $\left(7.00 \times 10^{7}\right.$ cells. $\left.\mathrm{mL}^{-1}\right)$ with a lesser increase in the reservoir microbe biomass $\left(9.3 \times 10^{6}\right.$ cells $\left.\cdot \mathrm{mL}^{-1}\right)$. No changes in cell number were observed in the negative control (total cells: $2.3 \times 10^{6}$ cells $\cdot \mathrm{mL}^{-1}$; fluorescent cells $8.0 \times 10^{4}$ cells $\left.\cdot \mathrm{mL}^{-1}\right)$. No $E$. coli $16 \mathrm{~S}$ rDNA ARDRA fragments were detected in the microcosms fed E. coli biomass (data not shown), confirming that the increase in cell number was not due to growth of contaminating E. coli cells. The ARDRA patterns from 96 clones from each microcosm were similar (data not shown), indicating that the same microbial community responded to each nutrient feed, albeit the most diversity was observed in the molasses-fed microcosm (data not shown).

\section{The effect of microbial biomass on physical properties of the reservoir fluids}

Different amounts of microbial biomass had no significant effect on the density and viscosity of synthetic formation water (Table 2), whether the biomass was from endogenous microbes or E. coli. The biomass had surface-active properties with increasing amounts of biomass leading to significant decreases in the IFT of dodecanesynthetic formation water interfaces under all conditions tested $\left(25^{\circ} \mathrm{C}\right.$, $50^{\circ} \mathrm{C}$ and $50^{\circ} \mathrm{C}$ at $1000 \mathrm{psi}$; Figure 5). The formation of stable air bubbles prevented IFT values being obtained at $10^{9} \mathrm{cells} \cdot \mathrm{mL}^{-1}$. Greatest changes were observed under reservoir conditions $\left(50^{\circ} \mathrm{C}\right.$ at $\left.1000 \mathrm{psi}\right)$ where $10^{8}$ cells $\cdot \mathrm{L}^{-1}$.E. coli or reservoir microbes resulted in $68 \%$ and $50 \%$ reduction

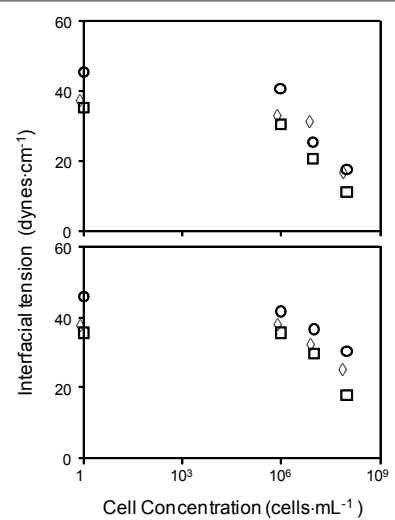

Figure 5: IFT changes at different conditions $\left(\circ 25^{\circ} \mathrm{C}\right.$ at ambient pressure, $\diamond$ $50^{\circ} \mathrm{C}$ at ambient pressure, and $\square 50^{\circ} \mathrm{C}$ at $1000 \mathrm{psi}$ ) as a function of (top figure) lysed $E$. coli cells and (bottom figure) lysed reservoir microorganisms.

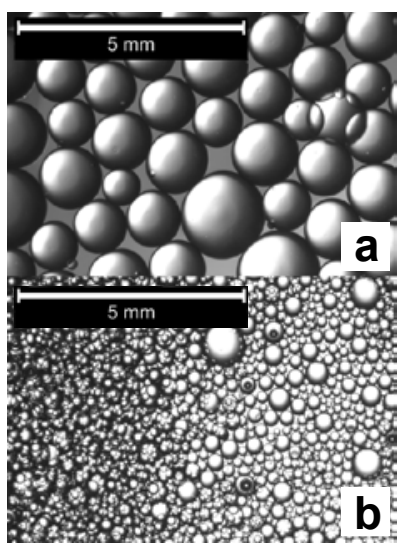

Figure 6: Microscope images of emulsified kerosene droplets formed with solutions of whole (a) or lysed (b) E. coli cells.

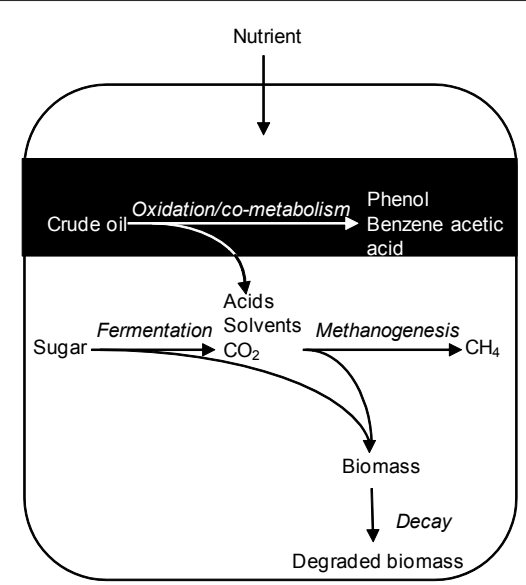

Figure 7: Summary of metabolic activities identified in petroleum reservoir microcosms after addition of nutrients. Metabolic activities are shown in italics. Specific biochemicals identified within reservoir fluids are described in the text and in Figure 3 and Table 1.

in IFT, respectively $\left(35.55\right.$, to 11.35 and 17.69 dynes $\left.\cdot \mathrm{cm}^{-1}\right)$. Both whole E. coli cell $\left(10^{9}\right.$ cells $\cdot \mathrm{mL}^{-1}: \mathrm{E}_{24}$ value $\left.33 \pm 2 \%\right)$ and lysed cell solutions ( $10^{8}$ cells $\cdot \mathrm{mL}^{-1}: \mathrm{E}_{24}$ value $44 \pm 2 \% ; 10^{9}$ cell $\cdot \mathrm{mL}^{-1}: \mathrm{E}_{24}$ value $6 \pm 3 \%$ ) were able to form stable emulsions. Emulsified kerosene droplets formed after addition of lysed $E$. coli cell solutions were smaller $(0.1-0.8 \mathrm{~mm})$ than the droplets formed with whole cell solutions (1-2 mm; Figure 6 ), suggesting a greater oil-water contact area. No stable emulsion was observed at lower cell concentrations or in the solutions without cells or cell components added. 


\section{Discussion}

The metabolic processes that occurred in response to MEOR were assessed after adding a variety of different nutrients into oil reservoir samples to change the 'status quo' of the microbial environment. Although carbon in the reservoir samples was abundant in the form of petroleum, an analysis of the reservoir oil indicated that it was highly biodegraded and depleted in compounds that would be readily bioavailable. When nutrients were added into the samples and the samples incubated under anaerobic conditions at $50^{\circ} \mathrm{C}$, the cell number did not increase in response to addition of nutrients combinations that did not include organic carbon (carbohydrate, protein or lipid). In conclusion, growth of the microbial community in the reservoir samples used in this study was limited by availability of carbon in forms accessible to the microbes. Addition of carbon based nutrients led to cell numbers in the microcosms increasing at least thousand-fold with the microbial community being dominated by Petrotoga, Mahella, Anaerobaculum, Flexistipes, Methanoculleus, Methanothermobacter and Methanocalculus. Sequences from all these groups have previously been identified in petroleum reservoirs [20,38-47].

The biochemical and biodiversity analysis of microcosms after nutrient addition suggested four dominant sources of metabolic byproducts (Figure 7): fermentation of the nutrient (accumulation of low and medium weight acids and alcohols; carbon dioxide); methanogenesis from the metabolites of the nutrient fermentation (accumulation of methane); metabolism and/or decay of biomass (increase in cell number); and oxidation/co-metabolism of compounds in the crude oil fraction (accumulation of mid-molecular weight alcohols and acids including 1-pentanol, phenol and benzene acetic acid, that are not expected from carbohydrate metabolism). The cometabolism of bio-recalcitrant compounds by microbial consortia after addition of carbohydrate is commonly reported in other systems and is frequently exploited in bioremediation technologies [48,49].

Many previous studies have listed the by-products of fermentation and methanogenic pathways as key components to successful MEOR. However, the ability of these metabolites to enhance oil recovery has been brought into question by studies predicting that these metabolites, in the quantities that they are likely to be produced after nutrient addition to an anearobic reservoir, have little potential to move oil [50]. Here, we found some evidence for co-metabolism/oil oxidation of the oil component on a timescale relevant to MEOR, which is believed to represent serendipitous molecular transformations of no or minimal metabolic value that have occurred in parallel to microbial metabolism. However, the scale of these transformations is unlikely to be significant for MEOR. The final pathway we identified in this study-biomass accumulation/decay-has not received much attention in relation to MEOR and therefore we investigated the physical and nutritional effects of biomass on reservoir communities and fluids in further detail (see below).

Previous studies investigating the effect of biomass on MEOR have focused primarily on effects of whole cells: bioplugging $[2,8,20,24]$, emulsification effects [21-23] or wettbility [19,25]. In this study we extended these earlier studies by investigated whether disrupted microbial biomass (cellular components) could be utilised as a nutrient source by the extant microbial community and what effect the addition of biomass had on the physical properties of the reservoir fluids. Most commonly the biomass used in this study was intended to mimic decaying microbial cell matter and was prepared by autoclaving microbial cells. As the chemical composition of microbes varies, biomass was derived from both $E$. coli and reservoir microbial cell pellets. It is expected that the process of autoclaving the cells would disrupt membranes and disperse the cellular contents. Thus the 'biomass' is a combination of the insoluble cell membrane and wall components as well as the soluble cellular components. Given the nature of these components, it is expected that the soluble cellular compounds would provide a rich nutrient source for microbes, and that the insoluble cell membrane and wall components would display surface-active properties.

In order to distinguish the effect of biomass as a nutrient from the general effects observed after adding nutrients into the reservoir, biomass was grown independently and then added into microcosms. Biomass led to large increases in cell number indicating that it could

\begin{tabular}{|c|c|c|c|c|c|c|}
\hline $\begin{array}{l}\text { Surface active } \\
\text { compound and source }\end{array}$ & $\begin{array}{l}\text { IFT drop } \\
\text { measured } \\
(\%)\end{array}$ & $\begin{array}{l}\text { Amount of surface active } \\
\text { compound used }\left(\mathrm{mg} \cdot \mathrm{L}^{-1}\right)\end{array}$ & $\begin{array}{l}\text { Cell mass used to make } \\
\text { compound }(\mathrm{mg})\end{array}$ & $\begin{array}{l}\text { Yield of surface active } \\
\text { compound per cell } \\
\text { weight }\left(g \cdot g^{-1}\right)\end{array}$ & $\begin{array}{l}\mathrm{EOR}^{1} \\
(\%)\end{array}$ & References \\
\hline E. coli cell biomass & $57-68$ & $28^{2}$ & 28 & 1 & Not tested & This study \\
\hline $\begin{array}{l}\text { Lipopeptide from } \\
\text { Bacillus mojavensis }\end{array}$ & $\begin{array}{l}\text { Drop to } 0.006 \\
\mathrm{mN} \cdot \mathrm{m}^{-1}\end{array}$ & $5-56$ & $74-824^{4}$ & 0.068 & 21-39 (BS, SP, L) & {$[52,58-64]$} \\
\hline $\begin{array}{l}\text { Lipopeptide from } \\
\text { Bacillus subtilis }\end{array}$ & $59-86$ & $1000-3000$ & $2222-6667^{5}$ & 0.45 & 25-61 (SP) & [65-69] \\
\hline $\begin{array}{l}\text { Rhamnolipid from } \\
\text { Pseudomonas } \\
\text { aeruginosa }^{6}\end{array}$ & $>99$ & 100 & Not described & & 42 (SP) & [70] \\
\hline $\begin{array}{l}\text { Biosurfactant from } \\
\text { Pseudomonas } \\
\text { aeruginosa }\end{array}$ & $47-57$ & 10 or not described & $13.9-30.3^{7}$ & $0.33-0.72$ & $50-85$ (SP) & [71-73] \\
\hline $\begin{array}{l}\text { Microbial cells and } \\
\text { metabolites after } \\
\text { fermentation }\end{array}$ & $24-98$ & Not described & Not described & & 7-86 (BS, SP, L) & {$[9,58,74-78]$} \\
\hline
\end{tabular}

${ }^{1} \mathrm{EOR}$ : Enhanced oil recovery observed in laboratory studies using core type: Berea sandstone core (BS), sand packed column (SP), limestone (L).

${ }^{2}$ The value was calculated according to a single E. coli cell weight $2.8 \times 10^{-13} \mathrm{~g}[79]$.

${ }^{3}$ Formally $B$. licheniformis JF-2 [80].

${ }^{4} 500 \mathrm{mg} \cdot \mathrm{L}^{-1}$ of dry Bacillus mojavensis yields $34 \mathrm{mg} \cdot \mathrm{L}^{-1}$ lipopeptide [61]

${ }^{5}$ The yield of biosurfactant per dry cell weight was $0.45 \mathrm{~g} \cdot \mathrm{g}^{-1}[68,81]$

${ }^{6}$ Engineered with the RhIAB: rhamnosyltransferase complex for synthesis of rhamnose.

${ }^{7}$ The yield of biosurfactant per dry cell weight was $0.33-0.72 \mathrm{~g} \cdot \mathrm{g}^{-1}[71]$.

Table 3: Described properties of surface active compounds investigated for enhancing oil recovery. 
serve as a nutrient source capable of promoting significant microbial growth. ARDRA patterns indicated that biomass derived from different sources (E. coli or reservoir microbes) stimulated growth of similar communities. Numerous studies and commercial operations have involved the injection of microbes into reservoirs, generally as an inocculant [13]. However, few studies document that these microbes can become established in the reservoir [51]. Our results suggest that in many cases where microbes are added into a reservoir, they will be utilised as a nutrient source by the extant microbial community. Similarly, if nutrients are added into a reservoir to target growth of specific microbial communities, then the resultant increase in biomass can serve as a nutrient source for subsequent non-target communities.

In addition to nutritional effects, the microbial biomass had significant surface-active properties. In agreement with other studies [22-24], it was found that whole cells were able to form stable emulsions. Equivalent amounts of biomass as cell components (lysed cells) could also emulsify the oil, and with higher efficiency. The biomass had significant effects on the IFT with effects similar to those observed with specific biosurfactants investigated for MEOR (Table 3). In this study, the addition of $28 \mathrm{mg} \cdot \mathrm{L}^{-1}$ biomass reduced the dodecane-synthetic formation water IFT over 50\% under reservoir conditions. Previously, the biomass of the prolific biosurfactant producer Bacillus mojavensis (formally B. licheniformis JF-2) had also been shown to have significant surface active properties (in addition to the effect of the surfactant that it secretes) with surface active properties reduced by $32 \%$ when cells were removed from the test fluids [52]. The surface active compounds in the biomass are most likely cell membrane components such as phospholipids, which have critical micelle concentration (CMC) values (a few $10 \mathrm{~s} \mathrm{of} \mathrm{mg} \cdot \mathrm{L}^{-1}$ ) in the range of 0.01 to 10 dynes.cm ${ }^{-1}$, much lower than synthetic detergents (e.g. sodium dodecyl sulfate with a CMC of $2888.3 \mathrm{mg} \cdot \mathrm{L}^{-1}[12,53,54]$.

It is widely assumed that biosurfactants are the most effective microbial metabolites for altering interfacial properties of reservoir fluids $[7,51,55]$. The finding that biomass in its own right has similar surface active properties to biosurfactants that have been demonstrated to enhance oil recovery (Table 3 ) suggests that, in addition to specific biosurfactant production, manipulation of reservoir biomass levels should be considered for MEOR. Generally, biosurfactant metabolic pathways are controlled by the microbial nutritional environment $[56,57]$. Whilst biosurfactant production can be controlled in the laboratory by manipulating nutrient levels surrounding the microbes, it is obviously much more challenging to exert any level of nutritional control within the reservoir environment. In comparison, biomass is relatively easy to generate. We therefore recommend that further studies be undertaken to investigate the utility of microbial biomass for manipulation of reservoir fluid properties that may lead to MEOR.

\section{References}

1. Felber BJ (2004) Selected U. S. Department of Energy EOR technology applications. Society of Petroleum Engineers/Deparment of Energy Symposium on Improved Oil Recovery. Oklahoma, USA.

2. Sen R (2008) Biotechnology in petroleum recovery: The microbial EOR. Progress in Energy and Combustion Science 34: 714-724.

3. Magot M, Ollivier B, Patel BKC (2000) Microbiology of petroleum reservoirs. Antonie Van Leeuwenhoek 77: 103-116.

4. van Hamme JD, Singh A, Ward OP (2003) Recent advances in petroleum microbiology. Microbiol Mol Biol Rev 67: 503-549.
5. Rölling WF, Head IM, Larter SR (2003) The microbiology of hydrocarbon degradation in subsurface petroleum reservoirs: perspectives and prospects. Res Microbiol 154: 321-328.

6. Baviere M (1991) Basic Concepts in Enhanced Oil Recovery Processes. Elsevier Applied Science.

7. Mclnerney MJ, Nagle DP, Knapp RM (2005) Microbially enhanced oil recovery: past, present and future. In Ollivier B, Magot M (ed) Petroleum Microbiology ASM Press.

8. Jenneman GE, Moffitt PD, Young GR (1996) Application of a microbia selective-plugging process at the North Burbank unit: prepilot tests. SPE Production \& Facilities 11: 11-17.

9. Kowalewski E, Rueslåtten I, Steen KH, Bødtker G, Torsæter O (2006) Microbia improved oil recovery-bacterial induced wettability and interfacial tension effects on oil production. Journal of Petroleum science and Engineering 52 275-286.

10. Kumar AS, Mody K, Jha B (2007) Bacterial exopolysaccharides - a perception J Basic Microbiol 47: 103-117.

11. Lazar I, Petrisor IG, Yen TE (2007) Microbial enhanced oil recovery (MEOR). Pet Sci Technol 25: 1353-1366.

12. Singh A, van Hamme JD, Ward OP (2007) Surfactants in microbiology and biotechnology: Part 2. Application aspects. Biotechnology Advances 25: 99121.

13. Volk H, Hendry $P$ (2010) Oil recovery: fundamental approaches and principles of microbially enhanced oil recovery. In: Timmis KN (ed) Handbook of Hydrocarbon and Lipid Microbiology, Springer-Verlag.

14. Volk H, Liu K (2010) Experiences and economics of microbially enhanced oi recovery (MEOR). In: Timmis KN (ed) Handbook of Hydrocarbon and Lipid Microbiology, Springer-Verlag.

15. Youssef N, Elshahed MS, Mcinerney MJ (2009) Microbial processes in oil fields: culprits, problems, and opportunities. Adv Appl Microbiol 66: 141-251.

16. Feng Q, Ni F, Qin B, Ma X, Ji C, et al. (2006) Review of MEOR technology application in Dagang oilfield for the last decade. Society of Petroleum Engineers. SPE Asia Pacific Oil \& Gas Conference and Exhibition.

17. Lappin-Scott HM, Cusack F, Costerton JW (1988) Nutrient resuscitation and growth of starved cells in sandstone cores: a novel approach to enhanced oil recovery. Appl Environ Microbiol 54: 1373-1382.

18. Liu J, Ma L, Mu B, Liu R, Ni F, et al. (2005) The field pilot of microbial enhanced oil recovery in a high temperature petroleum reservoir. Journal of Petroleum Science and Engineering 48: 265-271.

19. Afrapoli MS, Crescente C, Alipour S, Torsaeter O (2009) The effect of bacterial solution on the wettability index and residual oil saturation in sandstone. Journal of Petroleum Science and Engineering 69: 255-260.

20. Davey ME, Gevertz D, Wood WA, Clark JB, Jenneman GE (1998) Microbia selective plugging of sandstone through stimulation of indigenous bacteria in a hypersaline oil reservoir. Geomicrobiol J 15: 335-352.

21. Dorobantu LS, Yeung AK, Foght JM, Gray MR (2004) Stabilization of oil-water emulsions by hydrophobic bacteria. Appl Environ Microbiol 70: 6333-6336.

22. Kang Z, Yeung A, Foght JM, Gray MR (2008) Hydrophobic bacteria at the hexadecane-water interface: examination of micrometre-scale interfacial properties. Colloids Surf B Biointerfaces 67: 59-66.

23. Kang Z, Yeung A, Foght JM, Gray MR (2008) Mechanical properties of hexadecane-water interfaces with adsorbed hydrophobic bacteria. Colloids Surf B Biointerfaces 62: 273-279.

24. Yakimov MM, Amro MM, Bock M, Boseker K, Fredrickson HL, et al. (1997) The potential of Bacillus licheniformis strains for in situ enhanced oil recovery. Journal of Petroleum Science and Engineering 18: 147-160.

25. Zargari S, Ostvar S, Niazi A, Ayatollahi S (2010) Atomic force microscopy and wettability study of the alteration of mica and sandstone by a biosurfactantproducing bacterium Bacillus thermodenitrificans. Journal of Advanced Microscopy Research 5: 143-148. 
Citation: Wang X, Li D, Hendry P, Volk H, Rashid A, et al. (2012) Effect of Nutrient Addition on an Oil Reservoir Microbial Population: Implications for Enhanced Oil Recovery. J Pet Environ Biotechnol 3:118. doi:10.4172/2157-7463.1000118

26. Stewart TL, Fogler HS (2002) Pore-scale investigation of biomass plug development and propagation in porous media. Biotechnol Bioeng 77: 577-588.

27. Karim MGA, Salim MAH, Zain ZM, Talib NN (2001) Microbial enhanced oil recovery (MEOR) technology in Bokor Field, Sarawak. SPE 72125. Society of Petroleum Engineers Asia Pacific Improved Oil Recovery Conference.

28. George SC, Volk H, Ahmed M, Pickel W, Allan T (2007) Biomarker evidence for two sources for solid bitumens in the Subu wells: Implications for the petroleum prospectivity of the East Papuan Basin. Organic Geochemistry 38: 609-642.

29. Sober HA (1968) Handbook of Biochemistry. Chemical Rubber Co.

30. Vrede K, Heldal M, Norland S, Bratbak G (2002) Elemental composition (C, N, P) and cell volume of exponentially growing and nutrient-limited bacterioplankton. Appl Environ Microbiol 68: 2965-2971

31. Doddema HJ, Vogels GD (1978) Improved identification of methanogenic bacteria by fluorescence microscopy. Appl Environ Microbiol 36: 752-754.

32. Lane DJ (1991) 16S/23S rRNA sequencing. In: Stackebrandt E, Goodfellow M (ed) Nucleic Acid Techniques in Bacterial Systematics. Academic Press.

33. DeLong EF (1992) Archaea in coastal marine environments. Proc Natl Acad Sci U S A 89: 5685-5689.

34. Cooper DG, Goldenberg BG (1987) Surface-active agents from two Bacillus species. Appl Environ Microbiol 53: 224-229.

35. Dickson AG, Goyet C (1994) DOE Handbook of methods for the analysis of the various parameters of the carbon dioxide system in sea water; version 2. ORNL/CDIAC-74.

36. Volkman JK, Alexander R, Kagi RI, Rowland SJ, Sheppard PN (1984) Biodegradation of aromatic hydrocarbons in crude oils from the Barrow subbasin of Western Australia. Organic Geochemistry 6: 619-632.

37. Head IM, Jones DM, Larter SR (2003) Biological activity in the deep subsurface and the origin of heavy oil. Nature 426: 344-352.

38. Ng TK, Weimer PJ, Gawel LJ (1989) Possible nonanthropogenic origin of two methanogenic isolates from oil-producing wells in the san miguelito field, ventura county, California. Geomicrobiol J 7: 185-192.

39. Rees GN, Patel BK, Grassia GS, Sheehy AJ (1997) Anaerobaculum thermoterrenum gen. nov., sp. nov., a novel, thermophilic bacterium which ferments citrate. Int J Syst Bacteriol 47: 150-154.

40. Lien T, Madsen M, Rainey FA, Birkeland NK (1998) Petrotoga mobilis sp. nov., from a North Sea oil-production well. Int J Syst Bacteriol 48: 1007-1013.

41. L'Haridon S, Miroshnichenko ML, Hippe H, Fardeau ML, Bonch-Osmolovskaya EA, et al. (2002) Petrotoga olearia sp. nov. and Petrotoga sibirica sp. nov., two thermophilic bacteria isolated from a continental petroleum reservoir in Western Siberia. Int J Syst Evol Microbiol 52: 1715-1722.

42. Miranda-Tello E, Fardeau ML, Joulian C, Magot M, Thomas P, et al. (2007) Petrotoga halophila sp. nov., a thermophilic, moderately halophilic, fermentative bacterium isolated from an offshore oil well in Congo. Int J Syst Evol Microbiol 57: 40-44.

43. Miranda-Tello E, Fardeau ML, Thomas P, Ramirez F, Casalot L, et al. (2004) Petrotoga mexicana sp. nov., a novel thermophilic, anaerobic and xylanolytic bacterium isolated from an oil-producing well in the Gulf of Mexico. Int J Syst Evol Microbiol 54: 169-174.

44. Magot M (2005) Indigenous microbiol communities in oil fields. In: Ollivier B, Magot M (ed) Petroleum Microbiology. ASM Press.

45. Orphan VJ, Taylor LT, HafenbradI D, Delong EF (2000) Culture-dependent and culture-independent characterization of microbial assemblages associated with high-temperature petroleum reservoirs. Appl Environ Microbiol 66: 700-711.

46. Salinas MB, Fardeau ML, Thomas P, Cayol JL, Patel BK, et al. (2004) Mahella australiensis gen. nov., sp. nov., a moderately thermophilic anaerobic bacterium isolated from an Australian oil well. Int J Syst Evol Microbiol 54: 2169-2173.

47. Pham VD, Hnatow LL, Zhang S, Fallon RD, Jackson SC, et al. (2009) Characterizing microbial diversity in production water from an Alaskan mesothermic petroleum reservoir with two independent molecular methods. Environ Microbiol 11: 176-187.
48. Horvath RS, Alexander M (1970) Cometabolism: a technique for accumulation of biochemical products. Can J Microbiol 16: 1131-1132.

49. Jones DM, Head IM, Gray ND, Adams JJ, Rowan AK, et al. (2008) Crude-oi biodegradation via methanogenesis in subsurface petroleum reservoirs. Nature 451: 176-180.

50. Gray MR, Yeung A, Foght JM (2008) Potential microbial enhanced oil recovery processes: a critial analysis. Society of Petroleum Engineers Annual Technical Conference and Exhibition.

51. Youssef N, Simpson DR, Duncan KE, Mclnerney MJ, Folmsbee M, et al. (2007) In situ biosurfactant production by Bacillus strains injected into a limestone petroleum reservoir. Appl Environ Microbiol 73: 1239-1247.

52. Mclnerney MJ, Javaheri M, Nagle DP Jr (1990) Properties of the biosurfactant produced by Bacillus licheniformis strain JF-2. J Ind Microbiol 5: 95-101.

53. Banat IM (1995) Biosurfactants production and possible uses in microbial enhanced oil recovery and oil pollution remediation: A review. Bioresour Technol 51: 1-12.

54. Rosenberg E, Ron EZ (1999) High- and low-molecular-mass microbial surfactants. Appl Microbiol Biotechnol 52: 154-162.

55. Georgiou G, Lin SC, Sharma MM (1992) Surface-active compounds from microorganisms. Biotechnology ( N Y) 10: 60-65.

56. Cameotra SS, Makkar RS (1998) Synthesis of biosurfactants in extreme conditions. Appl Microbiol Biotechnol 50: 520-529.

57. Davis DA, Lynch HC, Varley J (1999) The production of Surfactin in batch culture by Bacillus subtilis ATCC 21332 is strongly influenced by the conditions of nitrogen metabolism. Enzyme and Microbial Technology 25: 322 329 .

58. Adkins JP, Cornell LA, Tanner RS (1992) Microbial composition of carbonate petroleum reservoir fluids. Geomicrobiol J 10: 87-97.

59. Bryant RS, Douglas J (1988) Evaluation of microbial systems in porous media for EOR. SPE Reservoir Engineering 3: 489-495.

60. Bryant RS, Burchfield TE, Dennis DM, Hitzman DO (1990) Microbial-enhanced waterflooding: Mink unit project. SPE Reservoir Engineering 5: 9-13.

61. Lin SC, Carswell KS, Sharma MM, Georgiou G (1994) Continuous production of the lipopeptide biosurfactant of Bacillus licheniformis JF-2. Appl Microbiol Biotechnol 41: 281-285.

62. Maudgalya S, Mclnerney MJ, Knapp RM, Nagle DP, Folmsbee MJ (2004) Development of bio-surfactant based microbial enhanced oil recovery procedure. SPE 89473. Society of Petroleum Engineers /Deparment of Energy Fourteenth Symposium on Improved Oil Recovery.

63. Maudgalya S, Mclnerney MJ, Knapp RM, Nagle DP, Folmsbee MJ (2005) Teritiary oil recovery with microbial biosurfactant treatment of low-permeability berea sandstone cores. SPE94213. Society of Petroleum Engineers Production Operations Symposium.

64. Mclnerney MJ, Duncan KE, Youssef N, Fincher T, Maudgalya SK, et al. (2005) Development of microorganisms with improved transport and biosurfactant activity for enhanced oil recovery. Report to the Department of Energy, DE-FE02NT15321, Washington DC, USA.

65. Das K, Mukherjee AK (2007) Comparison of lipopeptide biosurfactants production by Bacillus subtilis strains in submerged and solid state fermentation systems using a cheap carbon source: some industrial applications of biosurfactants. Process Biochemistry 42: 1191-1199.

66. Johnson SJ, Salehi M, Eisert KE, Liang JT, Bala G, et al. (2007) Using Biosurfactants produced from agriculture process waster streams to improve oil recovery in fractured carbonate reservoirs. Society of Petroleum Engineers. International Symposium on Oilfield Chemistry.

67. Joshi S, Bharucha C, Desai AJ (2008) Production of biosurfactant and antifunga compound by fermented food isolate Bacillus subtilis 20B. Bioresource Technol 99: 4603-4608.

68. Makkar RS, Cameotra SS (1997) Utilization of molasses for biosurfactant production by two Bacillus strains at thermophilic conditions. J AM Oil Chem Soc 74: 887-889. 
Citation: Wang X, Li D, Hendry P, Volk H, Rashid A, et al. (2012) Effect of Nutrient Addition on an Oil Reservoir Microbial Population: Implications for Enhanced Oil Recovery. J Pet Environ Biotechnol 3:118. doi:10.4172/2157-7463.1000118

69. Makkar RS, Cameotra SS (1998) Production of biosurfactant at mesophilic and thermophilic conditions by a strain of Bacillus subtilis. J Ind Microbiol Biotechnol 20: 48-52.

70. Wang Q, Fang X, Bai B, Liang X, Shuler P, et al. (2007) Engineering bacteria for production of rhamnolipid as an agent for enhanced oil recovery. Biotechnol Bioeng 98: 842-853.

71. Bordoloi NK, Konwar BK (2008) Microbial surfactant-enhanced mineral oil recovery under laboratory conditions. Colloids Surf B Biointerfaces 63: 73-82.

72. Das K, Mukherjee AK (2005) Characterization of biochemical properties and biological activities of biosurfactants produced by Pseudomonas aeruginosa mucoid and non-mucoid strains isolated from hydrocarbon-contaminated soil samples. Appl Microbiol Biotechnol 69: 192-199.

73. Okpokwasili GW, Ibiene AA (2006) Enhancement of recovery of residual oi using a biosurfactant slug. Afr J Biotechnol 5: 453-456.

74. Abdulrazag YZ, Almehaideb RA, Chaalal O (1999) Project of increasing oil recovery from UAE reservoirs using bacteria flooding. SPE 56827. Society of Petroleum Engineers Annual Technical Conference and Exhibition.

75. Abu-Ruwaida AS, Banat IM, Haditirto S, Salem A, Kadri M (1991) Isolation of biosurfactant-producing bacteria product characterization, and evaluation. Acta Biotechnologica 11: 315-324.
76. Chang YI (1987) Preliminary studies assessing solium pyrophosphate effects on microbially mediated oil recovery. Annals of New York Academy of Sciences 506: 296-307.

77. Peihui H, Fengrong S, Mei S (2001) Microbial EOR laboratory studies on the microorganisms using petroleum hydrocarbon as a sole carbon source. SPE72128. Society of Petroleum Engineers Asia Pacific Improved Oil Recovery Conference.

78. Sugihardjo EH, Pratomo SW (1999) Microbial core flooding experiments using indigenous microbes. Society of Petroleum Engineers Asia Pacific Improved Oil Recovery Conference.

79. Bratbak G, Dundas I (1984) Bacterial dry matter content and biomass estimations. Appl Environ Microbiol 48: 755-757.

80. Folmsbee M, Duncan K, Han SO, Nagle D, Jennings E, et al. (2006) Reidentification of the halotolerant, biosurfactant-producing Bacillus licheniformis strain JF-2 as Bacillus mojavensis strain JF-2. Syst Appl Microbiol 29: 645-649.

81. Liu ZF, Zeng GM, Zhong H, Fu HY, Liu XL (2010) Production and characterization of biosurfactant from Bacillus subtilis ССТCC AB93108. Journal of Central South University of Technology 17: 516-521. 